Sains Malaysiana 49(1)(2020): 75-84

http://dx.doi.org/10.17576/jsm-2020-4901-09

\title{
Effect of Crystallinity of Zeolite Beta on Physicochemical Properties and Performance of Cobalt Catalysts
}

(Kesan Habluran Beta Zeolit pada Sifat Fisikokimia dan Prestasi Pemangkin Kobalt)

\author{
Piaw Phatai, Sirinuch Loiha, Sanchai Prayoonpokarach \& Jatuporn Wittayakun*
}

\begin{abstract}
In the present work, the effect of crystallinity of zeolite beta in a sodium form (NaBEA) on physicochemical properties and performance of NaBEA-supported cobalt catalysts was investigated. The incipient wetness impregnation method was utilized in the synthesis of NaBEA-supported cobalt catalysts with various Co loadings (4, 7 and 10 wt. \%). NaBEA materials with high and low crystallinities (NaBEA-H and NaBEA-L) were synthesized using fumed silica with aging times of 72 and 48 h, respectively. In comparison to NaBEA-L, higher XRD peak intensities and surface area were observed for NaBEA-H. After impregnation, NaBEA-L displayed better dispersion of Co species and lower reducibility than NaBEA-H due to stronger metal-support interaction. Catalytic performance for n-butane hydrogenolysis via Col NaBEA-H and Co/NaBEA-L catalysts was compared. In butane hydrogenolysis, the higher conversion was attained using Co/NaBEA-H with 7 and 10 wt. \% when compared to Co/NaBEA-L with similar loadings. Multiple hydrogenolysis occurred on all catalysts producing methane as the only product. The most effective catalyst was determined to be $7 \mathrm{Co} /$ NaBEA-H due to the higher surface area and uniform particles of the cobalt species.
\end{abstract}

Keywords: Butane hydrogenolysis; cobalt; crystallinity; metal dispersion; zeolite beta

\section{ABSTRAK}

Dalam kertas ini, kesan habluran beta zeolit dalam bentuk natrium (NaBEA) pada sifat fisikokimia dan prestasi pemangkin kobalt disokong-NaBEA dikaji. Kaedah impregnasi basah peringkat awal telah digunakan dalam sintesis pemangkin kobalt disokong-NaBEA dengan pelbagai pembebanan Co (4, 7 dan $10 \%$ bt.). Bahan NaBEA dengan habluran tinggi dan rendah (NaBEA-H dan NaBEA-L) telah disintesis menggunakan silika wasap dengan perumuran masa 72 dan 48 jam. Berbanding NaBEA-L, puncak keamatan XRD yang tinggi dan luas permukaan diperhatikan untuk NaBEA-H. Selepas impregnasi, NaBEA-L menunjukkan serakan spesies Co yang lebih baik dan pengurangan yang rendah daripada NaBEA-H disebabkan oleh interaksi sokongan logam yang kuat. Prestasi pemangkinan untuk hidrogenolisis n-butana melalui pemangkin Co/NaBEA-H dan Co/NaBEA-L telah dibandingkan. Dalam hidrogenolisis butana, penukaran tinggi telah dicapai menggunakan 7 and $10 \%$ bt. Co/NaBEA-H jika dibandingkan dengan Col NaBEA-L untuk pembebanan yang sama. Pelbagai hidrogenolisis berlaku kepada semua pemangkin yang mengeluarkan metana. Pemangkin yang paling berkesan adalah 7Co/NaBEA-H disebabkan luas permukaan yang tinggi serta zarah seragam spesies kobalt.

Kata kunci: Beta zeolit; butana hidrogenolisis; kobalt; habluran; serakan logam

\section{INTRODUCTION}

Cobalt (Co) has been extensively used as a catalyst for various reactions such as hydrogenolysis of alkanes (Lomot et al. 2002), Fischer-Tropsch synthesis of hydrocarbons (Girardon et al. 2007) and oxidative coupling of methane (Chan \& Smith 1990). The active phase of cobalt for those reactions is the metallic form $\left(\mathrm{Co}^{0}\right)$ which can be generated by the reduction of cobalt oxides including $\mathrm{Co}_{3} \mathrm{O}_{4}$ and $\mathrm{CoO}$ (Jacobs et al. 2007).

To increase the amount of active metallic sites and minimize metal consumption, metal is dispersed on a support which is generally a porous material. Metal-support interaction has a direct influence on the reducibility of the as-prepared metal species (Girardon et al. 2007; Jacobs et al. 2007; Hong et al. 2009). A weak metal-support interaction allows metal species to migrate on the support and agglomerate to form large particles during heat treatment. Such large particles are normally easy to reduce to the active metallic form, but the number of active sites, mainly on the particle surface, is low. Alternatively, a strong metal-support interaction prevents migration of a metal species on the support resulting in good dispersion, but they are difficult to reduce.

In the case of cobalt, the oxide species supported on a high surface area material, such as $\mathrm{SiO}_{2}$, with weak interaction could be reduced at low temperatures (200$300^{\circ} \mathrm{C}$ ) (Jacobs et al. 2007). Jabloński et al. (2003) prepared cobalt on $\mathrm{SiO}_{2}$ with high and low surface areas (390 and 
$35 \mathrm{~m}^{2} / \mathrm{g}$, respectively). They found that the better cobalt dispersion was obtained on $\mathrm{SiO}_{2}$ with the higher surface area. In both cases, cobalt oxides were reduced completely at $400^{\circ} \mathrm{C}$. Alternatively, cobalt oxides supported on materials with strong interactions, such as $\mathrm{Al}_{2} \mathrm{O}_{3}$, could be reduced at higher temperatures $\left(400-700^{\circ} \mathrm{C}\right)(\mathrm{Jacobs}$ et al. 2007). Such higher reduction temperatures facilitated the migration of metal species on the support leading to the agglomeration of large particles, which yielded low catalytic activity. To prevent agglomeration during heat treatment, cobalt can be supported on a zeolite. The particular size of the channel or cage in zeolite can limit cobalt particle growth and thus improve cobalt dispersion.

There are reports that the reducibility of cobalt supported on zeolite depends on the preparation method used. Cobalt on NaY prepared by ion-exchange was not reducible because cobalt ions have low electrochemical reduction potential and strong interaction with the zeoliteframework oxygen (Guczi \& Kiricsi 1999). In contrast, half of the cobalt species on $\mathrm{NaY}$ prepared by impregnation could be reduced at $400^{\circ} \mathrm{C}$ and yielded a moderate conversion $(32 \%)$ in butane hydrogenolysis at $300^{\circ} \mathrm{C}$ (Khemthong et al. 2010).

A catalyst in which both the metal and support are active for a reaction is called a bifunctional catalyst. This type of catalyst is interesting because the performance of metals can be improved. Various types of zeolites are good examples of active supports. They have acidic sites for adsorption of reactants and uniform pores or cavities for shape and size selectivity of organic molecules. Bifunctional catalysts containing metals on zeolites are widely used in petroleum refining. NaBEA is a type of zeolite that has been widely used as a catalyst in various processes to convert hydrocarbon compounds by cracking (Altwasser et al. 2005), isomerization (Chao et al. 2000) and disproportionation (Čejka et al. 2004). For example, a bifunctional character was observed in cobalt supported on the nano-zeolite beta that was tested for the FischerTropsch reaction. Their catalytic activity depended on the concentration of metal and particle size, whereas selectivity for the formation of isoparafins was influenced by the zeolite acidity (Adebajo et al. 2005). In a study of oxidative benzene methylation with methane over H-ZSM-5, Co/ ZSM-5 and H-BEA, Adebajo et al. (2005) found that H-BEA, which has more acid sites than the others, gave the highest activity in benzene cracking. When compared with $\mathrm{NaY}$, USY, MCM-41 and MCM-22, Jansen et al. (1997) reported that NaBEA was the most effective catalyst yielding the highest conversion and selectivity in an organic conversion reaction.

The current study aims to improve the reducibility and catalytic performance of cobalt-based catalysts prepared by impregnation on NaBEA with various crystallinities. Zeolite beta (BEA) was chosen as a support because it has acid sites suitable for adsorption of organic compounds and could enhance the catalyzed reaction. BEA has threedimensional pores with dimensions of $0.55 \times 0.55$ and 0.76 $\times 0.64 \mathrm{~nm}$.
The crystallinity of zeolite is an important parameter that can be used to control the morphology and surface acidity of a catalyst. The degree of crystallinity from zeolite synthesis can be controlled by its varying aging times (Chansiriwat et al. 2016; Guo et al. 2001; Karami \& Rohani 2009) to allow more zeolite nuclei to form. A longer the aging time results in a greater number of nuclei and with a smaller crystal size. As the crystal size is decreased, the surface area and active acid sites are increased. Bressel et al. (2008) synthesized a Pd/H-ZSM-5 catalyst for dehydroalkylation of toluene with ethane and reported that high crystallinity zeolite improved the stability and selectivity of the catalyst. Guo et al. (2001) prepared a series of BEA/MCM-41 composites with various crystallinities. They observed that with increasing BEA crystallinity, the surface area and number of acid sites increased. This material exhibited higher catalytic activity for $n$-heptane cracking.

\section{Materials AND Methods}

\section{CHEMICALS}

Chemicals for the NaBEA synthesis were fumed silica $\left(\mathrm{SiO}_{2}\right.$, Merck), sodium hydroxide $(\mathrm{NaOH}, 97.0$ wt. \%, Carlo-Erba), sodium chloride ( $\mathrm{NaCl}, 99.5$ wt. \%, Merck), potassium chloride (KCl, 99.8 wt. \%, Univar), sodium aluminate $\left(\mathrm{NaAlO}_{2}, 55-56\right.$ wt. \%, Riedel-de Haën) and tetraethylammonium hydroxide (TEAOH, 40.0 wt. \%, Fluka). The precursor of the cobalt catalysts was cobalt nitrate hexahydrate $\left(\mathrm{Co}\left(\mathrm{NO}_{3}\right)_{2} \cdot 6 \mathrm{H}_{2} \mathrm{O}, 99.8 \mathrm{wt} . \%\right.$, Univar $)$.

\section{SYNTHESIS AND CHARACTERIZATION OF ZEOLITE BETA IN SODIUM FORM (NaBEA)}

Zeolite beta in the sodium form (NaBEA) was synthesized using a modified method from the literature (Loiha et al. 2009). TEAOH was used as a template to assist in the formation of the zeolite framework. A sodium silicate solution $\left(\mathrm{Na}_{2} \mathrm{SiO}_{3}\right)$ was prepared by dissolving fumed silica $(10.00 \mathrm{~g})$ in an aqueous $\mathrm{NaOH}$ solution $(0.22 \mathrm{M}, 15 \mathrm{~mL})$ followed by stirring for $48 \mathrm{~h}$. A $\mathrm{NaAlO}_{2}$ solution was separately prepared by the dissolution of $\mathrm{NaAlO}_{2}$ powder $(0.61 \mathrm{~g})$ in an aqueous $\mathrm{NaOH}$ solution $(0.22 \mathrm{M}, 5 \mathrm{~mL})$. Then, an electrolyte solution consisting of $\mathrm{NaCl}(0.18 \mathrm{~g})$ and $\mathrm{KCl}(0.49 \mathrm{~g})$ was added to the $\mathrm{Na}_{2} \mathrm{SiO}_{3}$ solution. The template solution $(30 \mathrm{~mL})$ was added and the resulting mixture was stirred for $24 \mathrm{~h}$. The $\mathrm{NaAlO}_{2}$ solution $(5 \mathrm{~mL})$ was added into the mixture and stirred for $48 \mathrm{~h}$. The resulting gel with a $\mathrm{Si} / \mathrm{Al}$ ratio of 13 was aged at room temperature under a static condition for 48 and $72 \mathrm{~h}$ to produce NaBEA with low and high crystallinity. These samples are referenced as NaBEA-L and NaBEA-H, respectively. The gels were transferred to a $125 \mathrm{~mL}$ Teflonlined stainless steel autoclave and crystallized under a static condition at $135^{\circ} \mathrm{C}$ for $72 \mathrm{~h}$. The resulting crystalline product was separated by centrifugation at $2500 \mathrm{rpm}$, 
washed with deionized water until the $\mathrm{pH}$ of the rinsing solution was neutral. It was then dried at $77^{\circ} \mathrm{C}$ for $24 \mathrm{~h}$. Finally, the template was removed by calcination at $550^{\circ} \mathrm{C}$ for $6 \mathrm{~h}$.

Both NaBEA-L and NaBEA-H were characterized using $\mathrm{X}$-ray diffraction (XRD, Bruker AXS diffractometer D5005) with $\mathrm{Cu} \mathrm{K} \alpha$ radiation (wavelength $=0.15406 \mathrm{~nm}$ ) scanning from 5 to $80^{\circ}$ at an increment of $0.02^{\circ}$ and a scan speed of $0.5 \mathrm{~s} / \mathrm{step}$. The crystallinity of NaBEA-L relative to that of NaBEA-H was done by comparing the area of the major BEA peak at $2 \theta=22.4^{\circ}$ of both samples (Camblor et al. 1998; Loiha et al. 2009; Nicolaides 1999).

$\mathrm{N}_{2}$ adsorption-desorption isotherms of NaBEA-L and NaBEA-H were obtained on a Micromeritics ASAP 2010. Before the measurements, each sample was dried at $110^{\circ} \mathrm{C}$ overnight and degassed at $300^{\circ} \mathrm{C}$ under vacuum for $6 \mathrm{~h}$. The analyses were performed at liquid nitrogen temperature. The surface area of each sample was determined using a BET method from the adsorption data.

PREPARATION OF CO/NaBEA CATALYSTS AND CHARACTERIZATION BY XRD

The $\mathrm{xCo} / \mathrm{NaBEA}-\mathrm{L}$ and $\mathrm{xCo} / \mathrm{NaBEA}-\mathrm{H}(\mathrm{x}=4,7$ and $10 \mathrm{wt}$. $\% \mathrm{Co}$ ) catalysts were prepared by incipient wetness impregnation using a solution of $\mathrm{Co}\left(\mathrm{NO}_{3}\right)_{2} \cdot 6 \mathrm{H}_{2} \mathrm{O}$ on NaBEA-L and NaBEAH. The catalysts were dried overnight at room temperature, followed by drying at $100^{\circ} \mathrm{C}$ for $3 \mathrm{~h}$ and then calcined at $300^{\circ} \mathrm{C}$ for $3 \mathrm{~h}$. The obtained $\mathrm{xCo} /$ NaBEA-L and $\mathrm{xCo} / \mathrm{NaBEA}-\mathrm{H}$ catalysts were analyzed using $\mathrm{XRD}$ as discussed above to observe changes in the BEA structure and the phases of cobalt oxides. In the case that oxide peaks were clearly observed, the crystal sizes of $\mathrm{Co}_{3} \mathrm{O}_{4}$ were calculated using Scherrer's equation: $\mathrm{t}=\mathrm{K} \lambda$ / $(\mathrm{B} \cos \theta)$ using the most intense reflection of $\mathrm{Co}_{3} \mathrm{O}_{4}$ crystallites at $2 \theta=36.9^{\circ}$, where $t$ is the average dimension of the crystallites (nm). K is the Scherrer constant, assumed to be $0.9 . \lambda$ is the $\mathrm{X}$-ray wavelength $(0.15406 \mathrm{~nm})$ and $\mathrm{B}$ is the corrected half-width at the half-maximum intensity of the reflection (in radians). The $\theta$ value is half of the $2 \theta$ the diffraction peak angle in radians (Bayati et al. 2008).

\section{PRETREATMENT OF CO/NaBEA CATALYSTS BY REDUCTION} AND CHARACTERIZATION BY XANES AND TEM

Since each catalyst was reduced by hydrogen before the catalytic testing, its reducibility in a similar treatment was studied using X-ray absorption near edge structure (XANES). Powders of each catalyst were subjected to uniaxial compression to form pellets that were crushed and sieved to obtain a material with particle sizes in the range of $250-450 \mu \mathrm{m}$. Approximately $0.05 \mathrm{~g}$ of the catalyst and $0.30 \mathrm{~g}$ of $\alpha-\mathrm{Al}_{2} \mathrm{O}_{3}$ were mixed and packed into a quartz wool bed in a quartz tube. It was then pretreated by heating from room temperature to $150^{\circ} \mathrm{C}$ with a ramp-up of $5^{\circ} \mathrm{C} /$ min under a $50 \mathrm{~mL} / \mathrm{min}$ He flow and held for $1 \mathrm{~h}$. After that, the catalyst was reduced under a pure $\mathrm{H}_{2}$ flow $(50 \mathrm{~mL} /$ min) with heating from 150 to $400^{\circ} \mathrm{C}$ with a ramp-up of $5^{\circ} \mathrm{C} / \mathrm{min}$ and held at the final temperature for $5 \mathrm{~h}$.
The form of cobalt in each catalyst after reduction was analyzed using XANES at a Co K-edge at room temperature in transmission mode at Beamline 8 of the Synchrotron Light Research Institute, Thailand. The energy calibration for scanning the X-ray energy was carried out using a Co standard foil (Exafs Material, Inc.) $(\mathrm{K}$ edge $=7709 \mathrm{eV})$. Each sample was pressed into a frame, covered using polyimide tape and mounted onto a sample holder. The photon energy was calibrated using Co foil. Normalization of the XANES spectra was carried out using the ATHENA program and the results compared with reference materials that included $\mathrm{Co}$ foil, $\mathrm{CoO}, \mathrm{Co}_{3} \mathrm{O}_{4}$, and $\mathrm{Co}\left(\mathrm{NO}_{3}\right)_{2}$. The percentage of reduced $\mathrm{Co}\left(\mathrm{Co}^{0}\right)$ from the reduction was determined using a Linear Combination Fit (LCF) tool in the ATHENA program with energy values ranging from -20 to $30 \mathrm{eV}$ from the edge energy.

The morphology as well as cobalt dispersion after reduction was investigated using transmission electron microscopy (TEM, TECNAI G ${ }^{2}$, FEI Company) with a 160 $\mathrm{kV}$ accelerating voltage. The reduced catalysts were dispersed in ethanol, dropped onto carbon-coated copper grids, dried at room temperature and transferred to the TEM chamber.

\section{CATALYTIC TESTING OF Co/NaBEA CATALYSTS FOR BUTANE HYDROGENOLYSIS}

The catalytic performance of the samples was investigated in a fixed-bed flow reactor. Each catalyst was packed in a quartz tube and reduced as described above. The catalyst was then cooled to $200^{\circ} \mathrm{C}$ under a He flow and a feed stream was introduced that consisted of $\mathrm{n}-\mathrm{C}_{4} \mathrm{H}_{10}, \mathrm{H}_{2}$ and $\mathrm{He}$ with the flow rates of $0.5,30.0$ and $69.5 \mathrm{~mL} / \mathrm{min}$, respectively. The first sampling via a GC sampling loop was done after 20 min at which time, steady-state was assumed. Then, the reactor temperature was increased by $30^{\circ} \mathrm{C}$ steps with a 20 min holding time at each step before sampling. This was continued to a final temperature of $410^{\circ} \mathrm{C}$. The reactants and products were analyzed using a GC (SRI GC 310C) equipped with a thermal conductivity detector (TCD). The catalyst with the best performance was characterized by $\mathrm{N}_{2}$ adsorption-desorption and TEM.

\section{RESUlts AND Discussion}

\section{PHYSICOCHEMICAL PROPERTIES OF NaBEA-L AND NaBEA-H}

The XRD patterns of the parent NaBEA-L and NaBEA-H are displayed in Figure 1(a). The main characteristic peaks of BEA were observed at $2 \theta=7.8^{\circ}$ and $22.4^{\circ}$ in both samples (Chen et al. 2004; Loiha et al. 2009). The peak intensities of NaBEA-H were higher than those of NaBEA-L suggesting greater crystallinity. By comparing areas of the BEA peaks at $2 \theta=22.4^{\circ}$, the crystallinity of NaBEA-L was about $75 \%$ relative to that of NaBEA-H. As the aging time of the synthesized BEA gel increased, the number of nuclei increased. With larger numbers of nuclei, a greater number 
of crystals were formed during crystallization. Thus, the obtained crystals had smaller average sizes because of the limited amount of silicate and aluminate in the gel (Byrappa \& Yoshimura 2001). With a large number of crystals, higher diffraction intensity and surface area were expected.

$\mathrm{N}_{2}$ adsorption-desorption isotherms of NaBEA-L and NaBEA-H are displayed in Figure 1(b). Both samples exhibited typical Type I isotherms in which the nitrogen uptake increased rapidly at a relatively low pressure $\left(\mathrm{P} / \mathrm{P}_{0}\right.$ $<0.1$ ) by adsorption in micropores and on external surfaces to form a monolayer (Storck et al. 1998). The volume adsorbed on NaBEA-L was lower than that on NaBEA-H and their BET surface areas were 387 and $639 \mathrm{~m}^{2} / \mathrm{g}$, respectively. In a sample with small crystals, the surface area (per weight) is high. The results from $\mathrm{N}_{2}$ adsorptiondesorption were in good agreement with the XRD results. At $\mathrm{P} / \mathrm{P}_{0}>0.9$, nitrogen uptake increased again because of the condensation of nitrogen to a liquid.

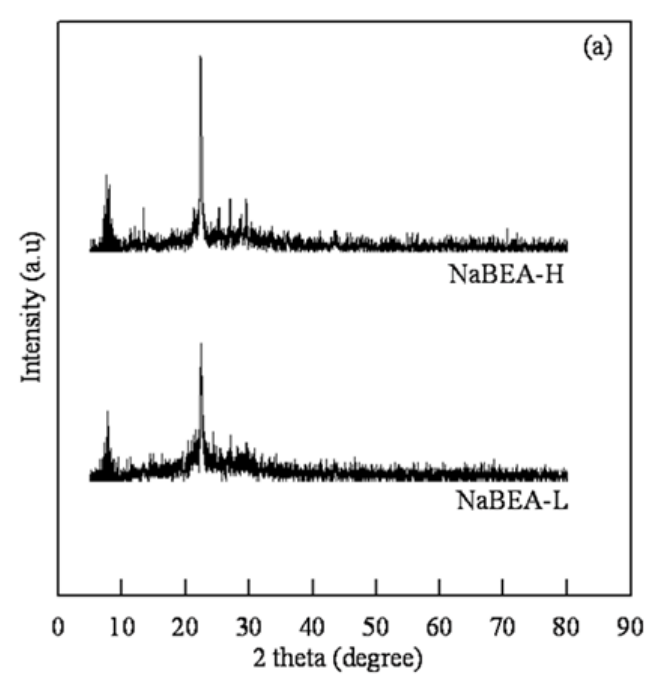

XRD ANALYSIS OF CALCINED xCo/NaBEA-L AND xCO/

$$
\text { NaBEA-H }
$$

The XRD patterns of $\mathrm{xCo} / \mathrm{NaBEA}-\mathrm{L}$ and $\mathrm{xCo} / \mathrm{NaBEA}-\mathrm{H}(\mathrm{x}$ $=4,7,10 \mathrm{wt} . \% \mathrm{Co}$ ) are shown in Figure 2(a) and 2(b), respectively. After cobalt loading, BEA peaks were still observed in all catalysts but their intensities decreased due to the presence of cobalt oxide particles on the zeolites that scattered the X-rays and decreased in the reflected intensity. Espinosa et al. (2011) reported decreases in diffraction peak heights of nanobeta-zeolites in proton form after impregnation with cobalt due to screening of X-rays by the cobalt oxide particles. The decrease in intensity was more evident with increased cobalt loading. However, the decrease of BEA diffraction peaks in our case was not consistently proportional to cobalt loading, probably because of differences in the zeolite form (i.e. sodium vs. proton) and morphology resulting from different synthetic approaches.

FIGURE 1. (a) XRD patterns and (b) $\mathrm{N}_{2}$ adsorption-desorption isotherms of parent zeolite
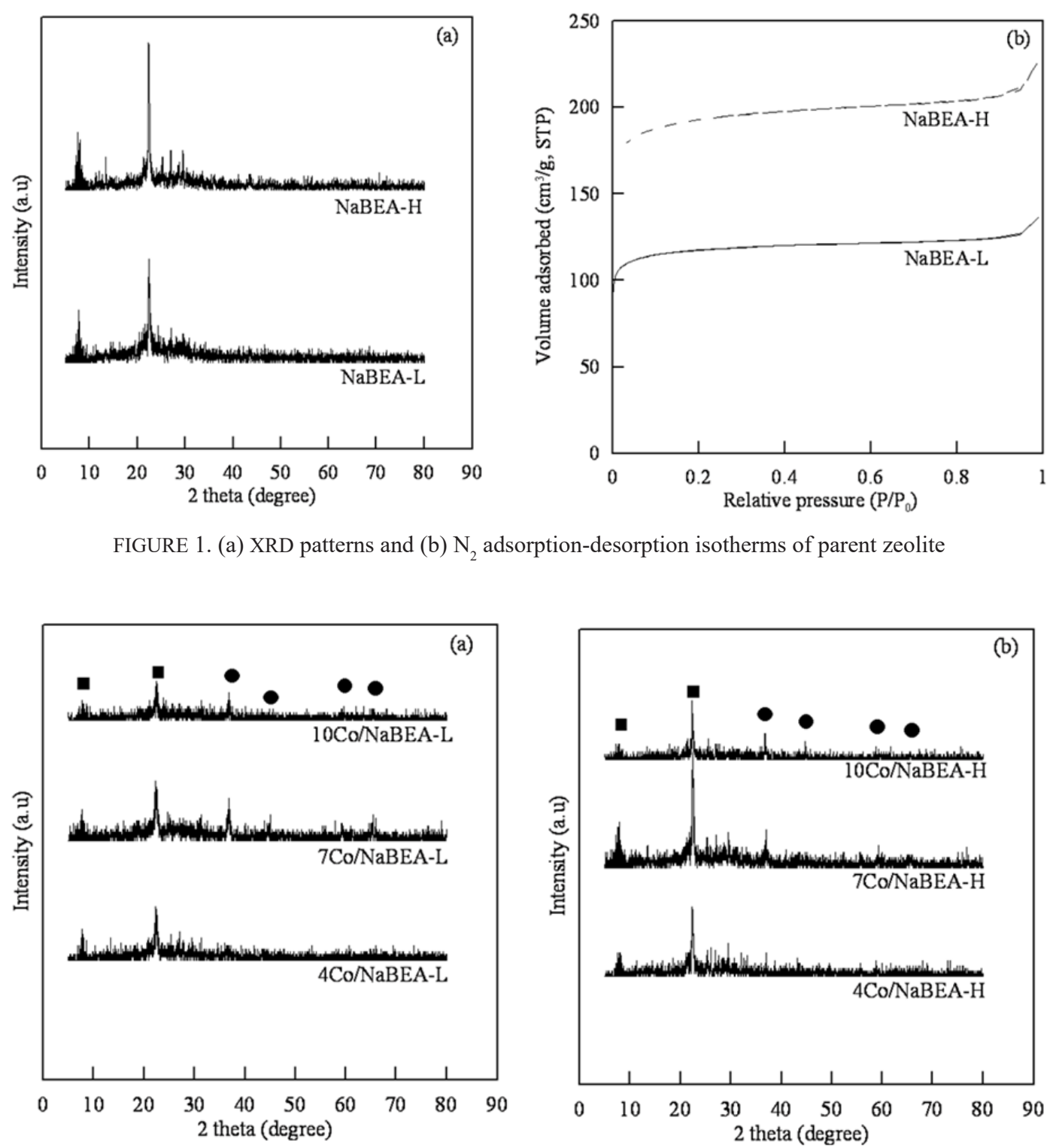

FIGURE 2. XRD patterns of calcined (a) xCo/NaBEA-L and (b) xCo/NaBEA-H; (•) NaBEA, (•) $\mathrm{Co}_{3} \mathrm{O}_{4}$ 
Peaks corresponding to $\mathrm{Co}_{3} \mathrm{O}_{4}$ at $2 \theta=36.9^{\circ}, 45.1^{\circ}$, $59.4^{\circ}$ and $65.4^{\circ}$ (JCPDS No. 42-1467, 43-1003) were not observed in the $4 \mathrm{Co} / \mathrm{NaBEA}-\mathrm{L}$ and $4 \mathrm{Co} / \mathrm{NaBEA}-\mathrm{H}$ suggesting good cobalt dispersion from low cobalt loading. In samples with 7 and 10 wt. \% loadings, only the first $\mathrm{Co}_{3} \mathrm{O}_{4}$ peak was observed indicating relatively larger particle sizes outside the zeolite channels. All four $\mathrm{Co}_{3} \mathrm{O}_{4}$ peaks were observed on $7 \mathrm{Co} / \mathrm{NaBEA}-\mathrm{L}$ suggesting that the cobalt oxide dispersion on this sample was poorer than that on $7 \mathrm{Co} / \mathrm{NaBEA}-\mathrm{H}$. The catalyst with better dispersion was expected to be more active in butane hydrogenolysis.

\section{XANES ANALYSIS OF xCo/NaBEA-L AND xCo/NaBEA-H AFTER REDUCED EX SITU}

The XANES spectra of cobalt standards, reduced ex situ $\mathrm{xCo} / \mathrm{NaBEA}-\mathrm{L}$ and $\mathrm{xCo} / \mathrm{NaBEA}-\mathrm{H}(\mathrm{x}=4,7$ and $10 \mathrm{wt} . \%)$ are shown in Figure 3. Information from the XANES analysis of the standards and catalysts, including positions of pre-edge energy, Co K-edge energy and white lines, are summarized in Table 1. The XANES data can be used as fingerprints of cobalt species to determine the oxidation state and site symmetry in the studied catalysts. The geometry of $\mathrm{CoO}$ cobalt species was octahedral and that of the $\mathrm{Co}_{3} \mathrm{O}_{4}$ was mixed tetrahedral and octahedral (Petitto et al. 2008). In $\mathrm{Co}\left(\mathrm{NO}_{3}\right)_{2}$, cobalt has octahedral coordination
(Chu et al. 2007). It is established that $\mathrm{Co}\left(\mathrm{NO}_{3}\right)_{2}$ transforms to $\mathrm{Co}_{3} \mathrm{O}_{4}$ after calcination at $150^{\circ} \mathrm{C}$ under an air flow (Girardon et al. 2007).

In Figure 3(a), the spectra of cobalt reference materials are similar to those reported in the literature (Girardon et al. 2007; Khemthong et al. 2010). The sharp rise is from $\mathrm{X}$-ray absorption which results in an injection of core electrons. The $\mathrm{K}$ edge is caused by an injection of an electron in the $\mathrm{K}$ shell and the $\mathrm{K}$ edge energy can be determined from the slope of the absorption spectra. The edge energy changes with the oxidation state and can be used to determine the oxidation number of specific elements. From Table 1, the K-edge values of cobalt foil, $\mathrm{CoO}, \mathrm{Co}_{3} \mathrm{O}_{4}$ and $\mathrm{Co}\left(\mathrm{NO}_{3}\right)_{2}$ are $7709.0,7720.7,7717.7$, and $7719.4 \mathrm{eV}$, respectively (Khemthong et al. 2010). The XANES spectra of $\mathrm{xCo} / \mathrm{NaBEA}-\mathrm{L}$ and $\mathrm{xCo} / \mathrm{NaBEA}-\mathrm{H}$ are shown in Figures 3(b) and 3(c), respectively. All cobalt catalysts had edge energies between 7721.0 and 7721.8 $\mathrm{eV}$, which are close to that of $\mathrm{CoO}$. This suggests that cobalt in these catalysts is cationic, although they were reduced ex situ prior to the XANES measurements. The composition of the cobalt species was further determined using Linear Combination Fitting with the ATHENA program (discussed in the next section).

Another important feature of the XANES spectra is its pre-edge, a small peak before the rise of the edge that is observed in some samples. These peaks are dipole (a) Standard compounds

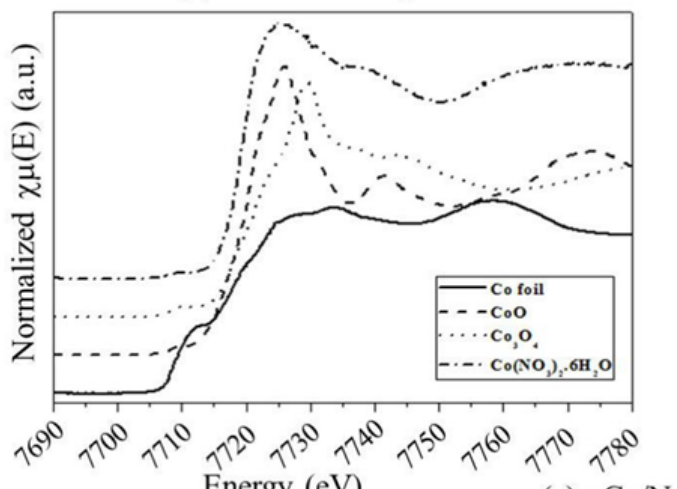

(c) $\mathrm{xCo} / \mathrm{NaBEA}-\mathrm{H}$

\section{(b) $\mathrm{xCo} / \mathrm{NaBEA}-\mathrm{L}$}

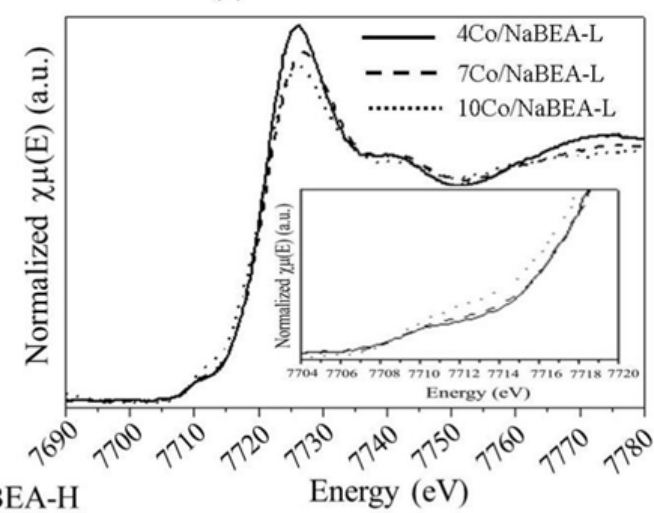

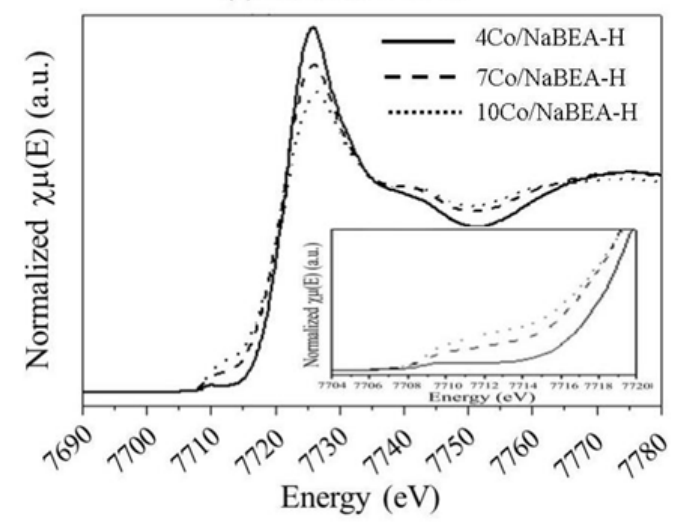

FIGURE 3. XANES spectra of (a) standard materials, (b) xCo/NaBEA-L and (c) xCo/NaBEA-H. The catalysts were reduced ex situ before measurement 
forbidden transitions from the $1 \mathrm{~s}$ to $3 \mathrm{~d}$ orbitals (Davis \& Occelli 2016). Except for the cobalt foil, the spectra of $\mathrm{CoO}, \mathrm{Co}_{3} \mathrm{O}_{4}$ and $\mathrm{Co}\left(\mathrm{NO}_{3}\right)_{2}$ consisted of a pre-edge peak at ca. $7708 \mathrm{eV}$ (Table 1). In the catalyst samples, pre-edge peaks were observed at ca. $7709 \mathrm{eV}$. From the insets Figures 3(b) and 3(c), the intensity after the pre-edge increased with increased Co loading. The most change was observed in the spectra of the catalysts with $10 \mathrm{wt}$ \% Co loading, indicating the most change after reduction. The change in pre-edge of the Co/NaBEA-H series was more noticeable than that of the Co/NaBEA-L series.

XANES spectra have white lines that reflect a hole in the d-orbital (vacancy) of an absorbing atom. The intensities depend on matrix elements and occupancy of any bound final state. White lines are very prominent for transition metals with high oxidation states such as metal oxide species. In this work, the white line peaks of NaBEAsupported cobalt were around $7726 \mathrm{eV}$, which is close to $\mathrm{CoO}$. The white line intensities decreased as the Co loading increased. The decrease in white line intensity with metal loading could suggest increased reducibility.

The percent cobalt composition in $\mathrm{xCo} / \mathrm{NaBEA}-\mathrm{L}$ and xCo/NaBEA-H suggested by Linear Combination Fitting (LCF) is shown in Table 2. In both the $\mathrm{xCo} / \mathrm{NaBEA}-\mathrm{L}$ and $\mathrm{xCo} / \mathrm{NaBEA}-\mathrm{H}$ series, the metallic form of cobalt was suggested only in the samples with cobalt loadings of 7 and 10 wt. $\%$. With a loading of 4 wt. $\%$, cobalt was well dispersed and had strong interaction with the zeolite, which could lead to the formation of $\mathrm{Co}_{3} \mathrm{O}_{4}$. The resulting reduction could then just partially transform $\mathrm{Co}_{3} \mathrm{O}_{4}$ to $\mathrm{CoO}$. The percentage of $\mathrm{Co}_{3} \mathrm{O}_{4}$ remaining in $4 \mathrm{Co} / \mathrm{NaBEA}-\mathrm{L}$ was higher than that in $4 \mathrm{Co} / \mathrm{NaBEA}-\mathrm{H}$, suggesting higher cobalt dispersion. A less uniform zeolite may have more defects or extra framework silicon oxide that could form strong interactions with cobalt species.

With a loading of $7 \mathrm{wt}$. \%, the remaining amount of $\mathrm{Co}_{3} \mathrm{O}_{4}$ in $7 \mathrm{Co} / \mathrm{NaBEA}-\mathrm{L}$ was also higher than that in $7 \mathrm{Co} /$ NaBEA-H, also suggesting better cobalt dispersion in NaBEA-L. Although the metallic cobalt was suggested in both series, the reduction temperature in our study was too low to transform the cobalt species into its metallic form. Bazin et al. (2000) reported that cobalt in $\mathrm{Co} / \mathrm{SiO}_{2}$ was not reduced in situ when tested at temperatures up to $650^{\circ} \mathrm{C}$. Additionally, the samples were reduced ex situ and exposed to air to some extent before the XANES analysis. Thus, metallic cobalt could be oxidized by air to form an oxide (Tompkins \& Augis 1981). Khodakov et al. (1997) reported that the reduction of $\mathrm{Co}_{3} \mathrm{O}_{4}$ in 24 wt. \% $\mathrm{Co}$ on $\mathrm{SiO}_{2}$ with hydrogen to $\mathrm{CoO}$ occurred at temperatures of $200-300^{\circ} \mathrm{C}$ and was further reduced to Co metal between $250-500^{\circ} \mathrm{C}$.

In $10 \mathrm{Co} / \mathrm{NaBEA}-\mathrm{L}$, the reducibility was higher than that in $7 \mathrm{Co} / \mathrm{NaBEA}-\mathrm{L}$ as confirmed by the higher metallic content with less $\mathrm{Co}_{3} \mathrm{O}_{4}$. In $10 \mathrm{Co} / \mathrm{NaBEA}-\mathrm{H}$, the percentage of $\mathrm{Co}_{3} \mathrm{O}_{4}$ and the metallic form was higher than for other loadings, suggesting that dispersion was poorer. Thus, the reducibility of cobalt in $\mathrm{Co} / \mathrm{NaBEA}-\mathrm{L}$ and $\mathrm{Co} / \mathrm{NaBEA}-\mathrm{H}$ increased with cobalt loading. With a loading of $10 \mathrm{wt}$. \%, the reduced 10Co/NaBEA-L and 10Co/NaBEA-H showed a similar composition. Thus, the cobalt reducibility depended on zeolite crystallinity only when the loading was 4 and 7 wt. \%. Wang and Chen (1991) reported that the extent of reduction of cobalt on $\mathrm{Al}_{2} \mathrm{O}_{3}$ increased with metal loading. At 1.5-6.0 wt. \% Co, the oxides could be only reduced at $800^{\circ} \mathrm{C}$. At 12 and $20 \mathrm{wt} . \% \mathrm{Co}$, the oxides could be reduced at lower temperatures.

\section{CATALYTIC PERFORMANCE OF xCo/NaBEA-L AND xCo/ NaBEA-H FOR BUTANE HYDROGENOLYSIS}

The percent conversions of butane from all $\mathrm{Co} / \mathrm{NaBEA}$ catalysts are shown in Figure 4. Methane was the only product from all catalysts suggesting that they facilitate multiple hydrogenolysis. At $200^{\circ} \mathrm{C}$ the conversions were low on all catalysts. Then, the conversions increased with temperature and complete conversions could be achieved using all catalysts, but at different temperatures. At 230 and $260^{\circ} \mathrm{C}$, the highest conversion was from $10 \mathrm{Co} /$ NaBEA-H followed by 7Co/NaBEA-H. They had similar conversions at higher temperatures. Since a lower content of Co was used to give a good performance, the $7 \mathrm{Co} /$

TABLE 1. Pre-edge energy position, main edge energy and white line position of cobalt standards, $\mathrm{xCo} / \mathrm{NaBEA}-\mathrm{L}$ and $\mathrm{xCo} /$ NaBEA-H

\begin{tabular}{lccc}
\hline Samples & Pre-edge energy $(\mathrm{eV})$ & Main edge energy $(\mathrm{eV})$ & White line position $(\mathrm{eV})$ \\
\hline $\mathrm{Co}$ foil & - & 7709.0 & 7727.3 \\
$\mathrm{CoO}$ & 7708.4 & 7720.7 & 7726.0 \\
$\mathrm{Co}_{3} \mathrm{O}_{4}$ & 7708.1 & 7717.7 & 7729.5 \\
$\mathrm{Co}\left(\mathrm{NO}_{3}\right)_{2}$ & 7708.0 & 7719.4 & 7725.0 \\
$4 \mathrm{Co} / \mathrm{NaBEA}-\mathrm{L}$ & 7709.0 & 7721.7 & 7726.0 \\
$7 \mathrm{Co} / \mathrm{NaBEA}-\mathrm{L}$ & 7709.0 & 7721.7 & 7726.8 \\
$10 \mathrm{Co} / \mathrm{NaBEA}-\mathrm{L}$ & 7709.3 & 7721.0 & 7726.0 \\
$4 \mathrm{Co} / \mathrm{NaBEA}-\mathrm{H}$ & $7709.0($ very small $)$ & 7721.8 & 7725.8 \\
$7 \mathrm{Co} / \mathrm{NaBEA}-\mathrm{H}$ & 7708.8 & 7721.5 & 7726.0 \\
$10 \mathrm{Co} / \mathrm{NaBEA}-\mathrm{H}$ & 7709.0 & 7721.6 & 7726.2 \\
\hline
\end{tabular}


TABLE 2. Percent cobalt composition in $\mathrm{xCo} / \mathrm{NaBEA}-\mathrm{L}$ and $\mathrm{xCo} / \mathrm{NaBEA}-\mathrm{H}$ suggested by LCF

\begin{tabular}{lccccccc}
\hline \multirow{2}{*}{ Samples } & \multirow{2}{*}{ Co loadings (wt. \%) } & \multicolumn{5}{c}{ Percent composition suggested by LCF (wt. \%) } \\
& & Co foil & $\mathrm{CoO}$ & $\mathrm{Co}_{3} \mathrm{O}_{4}$ & R-factor & Chi $^{2}$ & Reduced Chi $^{2}$ \\
\hline 4Co/NaBEA-L & 4 & 0.0 & 66.8 & 33.2 & 0.0015 & 0.2272 & 0.0013 \\
7Co/NaBEA-L & 7 & 10.5 & 44.8 & 44.7 & 0.0013 & 0.1808 & 0.0010 \\
10Co/NaBEA-L & 10 & 19.9 & 50.9 & 29.2 & 0.0016 & 0.2560 & 0.0011 \\
4Co/NaBEA-H & 4 & 0.0 & 82.5 & 17.5 & 0.0150 & 3.6963 & 0.0169 \\
7Co/NaBEA-H & 7 & 1.4 & 72.3 & 26.3 & 0.0033 & 0.7281 & 0.0030 \\
10Co/NaBEA-H & 10 & 20.3 & 51.7 & 28.0 & 0.0025 & 0.5189 & 0.0021 \\
\hline
\end{tabular}
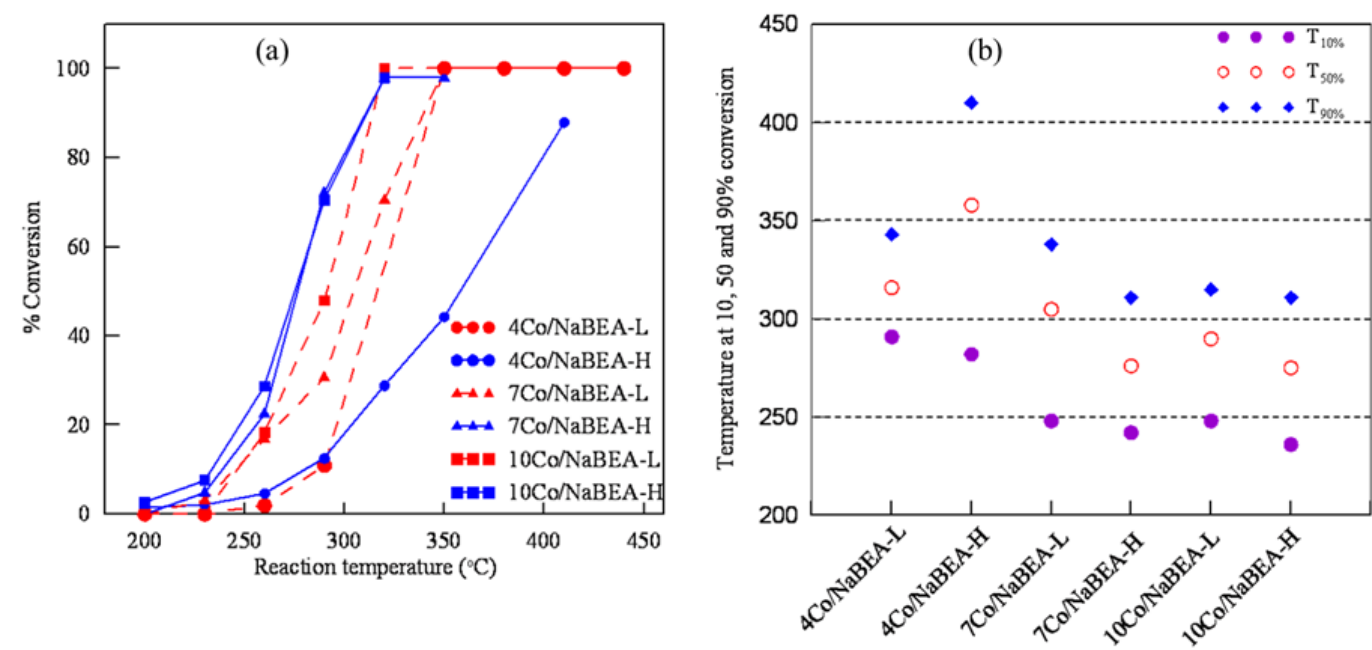

FIGURE 4. (a) Conversion in butane hydrogenolysis on supported Co catalysts; dashed line (red) = xCo/NaBEA-L, solid line (blue) $=\mathrm{xCo} / \mathrm{NaBEA}-\mathrm{H}$ (b) Temperatures of each catalyst in butane hydrogenolysis for 10,50 and $90 \%$ conversion

NaBEA-H was considered to be the best catalyst in this study. The percent conversion on $7 \mathrm{Co} / \mathrm{NaBEA}-\mathrm{H}$ at $290^{\circ} \mathrm{C}$ was $\sim 70 \%$, much higher than for $6 \mathrm{Co} / \mathrm{NaY}$ and $10 \mathrm{Co} / \mathrm{NaY}$ at $300^{\circ} \mathrm{C}$ as reported by Khemthong et al. (2010).

The catalytic activities of $\mathrm{Co} / \mathrm{NaBEA}$ catalysts are compared in Figure 4(b) in terms of temperatures that yielded 10,50 , and $90 \%$ conversion $\left(\mathrm{T}_{10 \%}, \mathrm{~T}_{50 \%}\right.$, and $\mathrm{T}_{90 \%}$, respectively). The catalyst which could reach a similar conversion at a lower reaction temperature was considered to be the more active catalyst. The catalysts providing the lowest $\mathrm{T}_{10 \%}, \mathrm{~T}_{50 \%}$, and $\mathrm{T}_{90 \%}$ were $7 \mathrm{Co} / \mathrm{NaBEA}-\mathrm{H}$ and $10 \mathrm{Co} /$ NaBEA-H. Better catalytic performance can be attributed to the suitable dispersion of highly crystalline cobalt on the zeolite. Although the results from XANES suggest lower reducibility for $7 \mathrm{Co} / \mathrm{NaBEA}-\mathrm{H}$ than for $7 \mathrm{Co} / \mathrm{NaBEA}-\mathrm{L}$, the reduction of $\mathrm{CoO}$ to metallic Co could also occur during the reaction because the feed stream contained hydrogen. Additionally, highly crystalline zeolite could facilitate the adsorption of reactants more effectively.

$7 \mathrm{Co} / \mathrm{NaBEA}-\mathrm{H}$ was considered the best catalyst. Therefore, it was further characterized using $\mathrm{N}_{2}$ adsorptiondesorption analysis and TEM and compared to $7 \mathrm{Co} /$ NaBEA-L.

\section{ANALYSIS OF 7CO/NABEA-L AND 7CO/NABEA-H BY N $\mathrm{N}_{2}$ ADSORPTION-DESORPTION AND TEM}

$\mathrm{N}_{2}$ adsorption-desorption isotherms of calcined 7Co/ NaBEA-L and 7Co/NaBEA-H are shown in Figure 5(a). Both of them exhibit Type I isotherms, similar to their bare supports, but their adsorbed volume decreased after cobalt loading. The surface area of $7 \mathrm{Co} / \mathrm{NaBEA}-\mathrm{H}$ was still higher than that of $7 \mathrm{Co} / \mathrm{NaBEA}-\mathrm{L}$ owing to the greater surface area of the parent zeolite. The higher surface area of the zeolite support facilitated the adsorption of reactants more effectively.

Figure 5(b) and 5(c) shows TEM images of ex situ reduced $7 \mathrm{Co} / \mathrm{NaBEA}-\mathrm{L}$ and $7 \mathrm{Co} / \mathrm{NaBEA}-\mathrm{H}$. Images of $7 \mathrm{Co} / \mathrm{NaBEA}-\mathrm{L}$ show dark spots of the cobalt species dispersed on the zeolites. The particle sizes of the cobalt species in both samples were quite similar, $\sim 20$ $\mathrm{nm}$. Since the particle sizes were much larger than the cavity of zeolite beta, $\sim 0.6 \times 0.7 \mathrm{~nm}$ (Baerlocher \& McCusker 2017), these particles were outside the pores. They could block the openings of some zeolite pores and result in decreased surface area after metal loading. 
(a) $\mathrm{N}_{2}$ adsorption-desorption isotherm

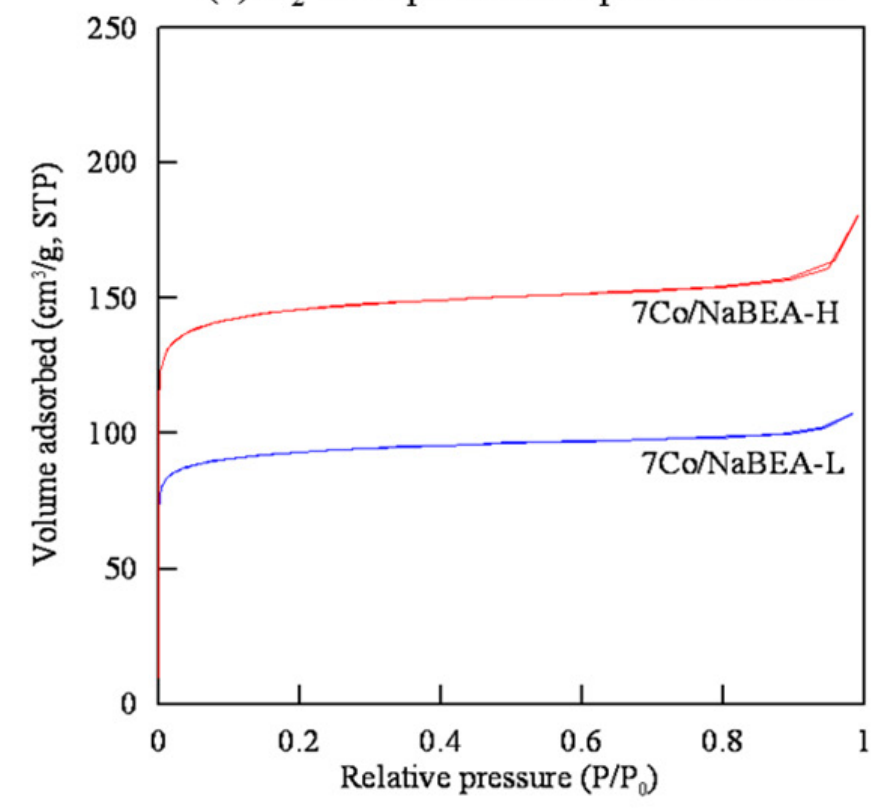

(b) $7 \mathrm{Co} / \mathrm{NaBEA}-\mathrm{L}$

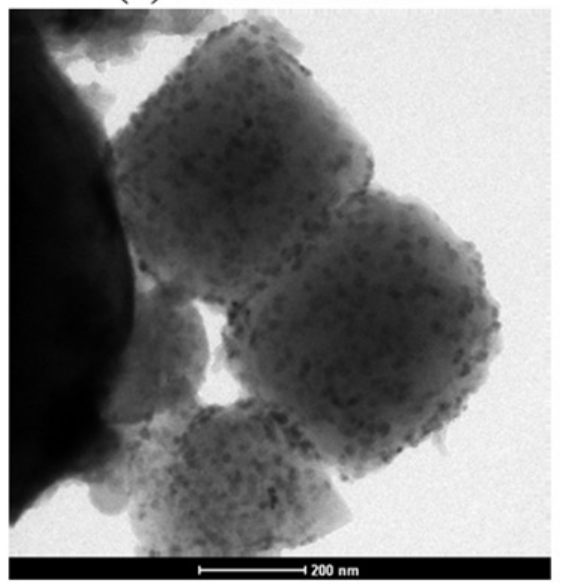

(c) $7 \mathrm{Co} / \mathrm{NaBEA}-\mathrm{H}$

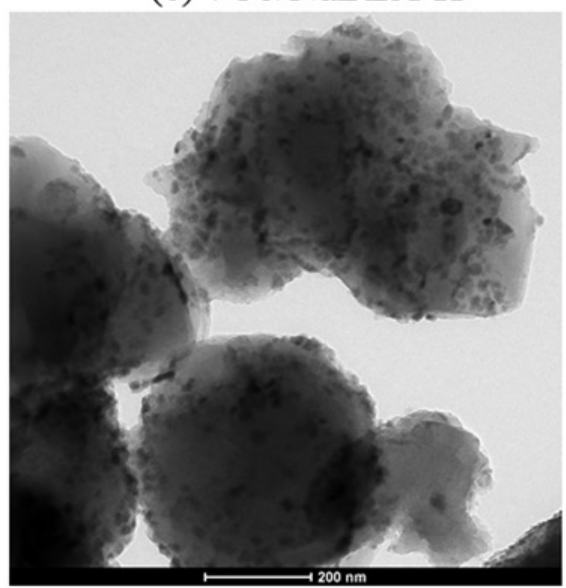

FIGURE 5. (a) $\mathrm{N}_{2}$ adsorption-desorption isotherms of calcined 7Co/NaBEA-L and 7Co/NaBEA-H, (b) TEM image of reduced $7 \mathrm{Co} /$ NaBEA-L (c) TEM image of reduced 7Co/NaBEA-H

\section{Conclusion}

Dispersion and reducibility of cobalt in a Co/NaBEA catalyst depend on the crystallinity of the zeolite. Cobalt had better dispersion on a zeolite with low crystallinity, resulting in lower reducibility and catalytic performance for butane hydrogenolysis. The most active catalyst in this work had a 7 wt. $\%$ of cobalt loaded on NaBEA-H giving low $\mathrm{T}_{10 \%}, \mathrm{~T}_{50 \%}$, and $\mathrm{T}_{90 \%}$ values. Multiple hydrogenolysis occurred with methane as the only product.

\section{ACKNOWLEDGEMENTS}

Financial support for this research was from Suranaree University of Technology (SUT). Scholarship for P. Phatai was from SUT and Udon Thani Rajabhat University, Thailand. The X-ray absorption beamtime was provided by the Synchrotron Light Research Institute, Thailand. Many thanks to Professor Dr. Jeffrey C. Nash from the
Office of Graduate Studies of the Udon Thani Rajabhat University (Thailand) for his assistance in proofreading this manuscript.

\section{REFERENCES}

Adebajo, M.O. \& Frost, R.L. 2005. Oxidative benzene methylation with methane over MCM-41 and zeolite catalysts: Effect of framework aluminum, $\mathrm{SiO}_{2} / \mathrm{Al}_{2} \mathrm{O}_{3}$ ratio, and zeolite pore structure. Energy Fuel 19(3): 783 790.

Altwasser, S., Welker, C., Traa, Y. \& Weitkamp, J. 2005. Catalytic cracking of n-octane on small-pore zeolites. Microporous and Mesoporous Materials 83(1-3): 345-356.

Baerlocher, C. \& McCusker, L.B. 2017. Database of Zeolite Structures. http://www.iza-structure.org/databases/.

Bayati, B., Babaluo, A.A. \& Karimi, R. 2008. Hydrothermal synthesis of nanostructure NaA zeolite: The effect of synthesis parameters on zeolite seed size and crystallinity. 
Journal of the European Ceramic Society 28(14): $2653-$ 2657.

Bazin, D., Kovács, I., Guczi, L., Parent, P., Laffon, C., De Groot, F., Ducreux, O. \& Lynch J. 2000. Genesis of Co/ $\mathrm{SiO}_{2}$ catalysts: XAS study at the cobalt LIII, II absorption edges. Journal of Catalysis 189(2): 456-462.

Bressel, A., Donauer, T., Sealy, S. \& Traa, Y. 2008. Influence of aluminum content, crystallinity and crystallite size of zeolite Pd/H-ZSM-5 on the catalytic performance in the dehydroalkylation of toluene with ethane. Microporous and Mesoporous Materials 109(1-3): 278-286.

Byrappa, K. \& Yoshimura, M. 2001. Handbook of Hydrothermal Technology-A Technology for Crystal Growth and Materials Processing. Norwich: William Andrew Publishing.

Camblor, M.A., Corma, A. \& Valencia, S. 1998. Characterization of nanocrystalline zeolite Beta. Microporous and Mesoporous Materials 25(1-3): 59-74.

Čejka, J., Kotrla, J. \& Krejči, A. 2004. Disproportionation of trimethyl benzenes over large pore zeolites: Catalytic and adsorption study. Applied Catalysis A: General 277(1-2): 191-199.

Chansiriwat, W., Tanangteerapong, D. \& Wantala, K. 2016. Synthesis of zeolite from coal fly ash by hydrothermal method without adding alumina and silica sources: Effect of aging temperature and time. Sains Malaysiana 45(11): 1723-1731.

Chan, T.K. \& Smith, K.J. 1990. Oxidative coupling of methane over cobalt-magnesium and manganese-magnesium mixed oxide catalysts. Applied Catalysis 60(1): 13-31.

Chao, K.J., Lin, C.C., Lin, C.H., Wu, H.C., Tseng, C.W. \& Chen, S.H. 2000. n-Heptane hydroconversion on platinumloaded mordenite and beta zeolites: The effect of reaction pressure. Applied Catalysis A: General 203(2): 211-220.

Chen, H.H., Shen, S.C., Chen, X.C. \& Kawi, S. 2004. Selective catalytic reduction of $\mathrm{NO}$ over Co/beta-zeolite: Effects of synthesis condition of beta-zeolites, Co precursor, Co loading method and reductant. Applied Catalysis B: Environmental 50(1): 37-47.

Chu, W., Chernavskii, P.A., Gengembre, L., Pankina, G.A., Fongerland, P. \& Khodakov, A.Y. 2007. Cobalt species in promoted cobalt alumina-supported Fischer-Tropsch catalysts. Journal of Catalysis 252(2): 215-230.

Davis, B.H. \& Occelli, M.L. 2016. Chapter 8: Fischer-Tropsch synthesis: Effect of $\mathrm{CO}$ conversion on product selectivities during deactivation or by changing space velocity at stable conditions over unpromoted and Ru-promoted $25 \% \mathrm{Co} /$ $\mathrm{Al}_{2} \mathrm{O}_{3}$ catalysts. In Fischer-Tropsch Synthesis, Catalysts, and Catalysis: Advances and Applications. 1st edition. Boca Raton: CRC Press. pp. 134-140.

Espinosa, G., Domínguez, J.M., Morales-Pacheco, P., Tobon, A., Aguilar, M. \& Benítez, J. 2011. Catalytic behavior of $\mathrm{Co} /(\mathrm{Nano} \beta$-Zeolite) bifunctional catalysts for FischerTropsch reactions. Catalysis Today 166(1): 47-52.

Girardon, J.S., Quinet, E., Griboval-Constant, A., Chernavskii, P.A., Gengembre, L. \& Khodakov, A.Y. 2007. Cobalt dispersion, reducibility, and surface sites in promoted silica-supported Fischer-Tropsch catalysts. Journal of Catalysis 248(2): 143-157.

Guczi, L. \& Kiricsi, I. 1999. Zeolite supported mono- and bimetallic systems: Structure and performance as $\mathrm{CO}$ hydrogenation catalysts. Applied Catalysis A: General 186(1-2): 375-394

Guo, W., Xiong, C., Huang, L. \& Li, Q. 2001. Synthesis and characterization of composite molecular sieves comprising zeolite Beta with MCM-41 structures. Journal of Materials Chemistry 11(7): 1886-1890.
Hong, J., Chernavskii, P.A., Khodakov, A.Y. \& Chu, W. 2009. Effect of promotion with ruthenium on the structure and catalytic performance of mesoporous silica (smaller and larger pore) supported cobalt Fischer-Tropsch catalysts. Catalysis Today 140(3-4): 135-141.

Jabloński, J.M., Okal, J., Potoczna-Petru, D. \& Krajczyk, L. 2003. High temperature reduction with hydrogen, phase composition, and activity of cobalt/silica catalysts. Journal of Catalysis 220(1): 146-160.

Jacobs, G., Ji, Y., Davis, B.H., Cronauer, D., Kropf, A.J. \& Marshall, C.L. 2007. Fischer-Tropsch synthesis: Temperature programmed EXAFS/XANES investigation of the influence of support type, cobalt loading, and noble metal promoter addition to the reduction behavior of cobalt oxide particles. Applied Catalysis A: General 333(2): 177191.

Jansen, J.C., Creyghton, E.J., Njo, S.L., van Koningveld, H. \& van Bekkum, H. 1997. On the remarkable behavior of zeolite Beta in acid catalysis. Catalysis Today 38(2): 205212.

Karami, D. \& Rohani, S. 2009. Synthesis of pure zeolite Y using soluble silicate, a two-level factorial experimental design. Chemical Engineering and Processing: Process Intensification 48(8): 1288-1292.

Khemthong, P., Klysubun, W., Prayoonpolarach, S., Roessner, F. \& Wittayakun, J. 2010a. Comparison between cobalt and cobalt-platinum supported on zeolite NaY: Cobalt reducibility and their catalytic performance for butane hydrogenolysis. Journal of Industrial and Engineering Chemistry 16(4): 531-538.

Khemthong, P., Klysubun, W., Prayoonpokarach, S., Roessner, F. \& Wittayakun, J. 2010b. Reducibility of cobalt species impregnated on $\mathrm{NaY}$ and $\mathrm{HY}$ zeolites. Materials Chemistry and Physics 212(1-2): 131-137.

Khodakov, A.Y., Lynch, J., Bazin, D., Rebours, B., Zanier, N., Moisson, B. \& Chaumette, P. 1997. Reducibility of cobalt species in silica-supported Fischer-Tropsch catalysts. Journal of Catalysis 168(1): 16-25.

Loiha, S., Prayoonpokatach, S., Songsiriritthigun, P. \& Wittayakun, J. 2009. Synthesis of zeolite beta with pretreated rice husk silica and its transformation to ZSM12. Materials Chemistry and Physics 115(2-3): 637-640.

Lomot, D., Juszczyk, W., Karpinski, Z. \& Larsson, R. 2002. Hydrogenolysis of ethane on silica-supported cobalt catalysts. Journal of Molecular Catalysis A: Chemical 186(1-2): 163-172.

Nicolaides, C.P. 1999. A novel family of solid acid catalysts: Substantially amorphous or partially crystalline zeolitic materials. Applied Catalysis A: General 185(2): 211217.

Petitto, S.C., Marsh, E.M., Carson, G.A. \& Langell, M.A. 2008. Cobalt oxide surface chemistry: The interaction of $\mathrm{CoO}(100), \mathrm{Co}_{3} \mathrm{O}_{4}(110)$ and $\mathrm{Co}_{3} \mathrm{O}_{4}(111)$ with oxygen and water. Journal of Molecular Catalysis A: Chemical 281(13): 49-58.

Storck, S., Bretinger, H. \& Maier, W.F. 1998. Characterization of micro- and mesoporous solids by physisorption methods and pore-size analysis. Applied Catalysis A: General 174(1-2): 137-146.

Tompkins, H.G. \& Augis, J.A. 1981. The oxidation of cobalt in air from room temperature to $467^{\circ} \mathrm{C}$. Oxidation of Metals 16(5-6): 355-369.

Wang, W.J. \& Chen, Y.W. 1991. Influence of metal loading on the reducibility and hydrogenation activity of cobalt/ alumina catalysts. Applied Catalysis 77(2): 223-233. 


\section{Piaw Phatai}

Department of Chemistry

Faculty of Science

Udon Thani Rajabhat University

Udon Thani 41000

Thailand

Sirinuch Loiha

Department of Chemistry

Faculty of Science

Khon Kaen University

Khon Kaen 40002

Thailand
Sanchai Prayoonpokarach \& Jatuporn Wittayakun* School of Chemistry

Institute of Science

Suranaree University of Technology

Nakhon Ratchasima 30000

Thailand

*Corresponding author; email: jatuporn@sut.ac.th

Received: 6 September 2019

Accepted: 10 October 2019 